\title{
Polymorphism, localization and geographical transfer of mitochondrial DNA in Mus musculus domesticus (Irish house mice)
}

\author{
A. W. RYAN, E. J. DUKE \& J. S. FAIRLEY* \\ Department of Zoology, University College, Dublin, Ireland and *Department of Zoology, University College, Galway, \\ Ireland
}

\begin{abstract}
The analysis of mtDNA restriction fragments from Irish house mice revealed much polymorphism, both within and between populations. Many phenotypes showed geographical localization and there was a strong correlation between geographical distance and genetic divergence. Populations, which are discontinuous and limited to buildings or their vicinity, are apparently the result of shortrange migration. Transport by man, with whom the species is closely associated, appears to have negligible impact. There is some evidence of the influence of topographical features on migration and consequent genetic interchange.
\end{abstract}

Keywords: mitochondrial DNA, Mus musculus, polymorphism.

\section{Introduction}

The house mouse Mus musculus domesticus (Auffray et al., 1990) has an almost world-wide distribution as a result of its commensal association with man. While it can survive in a great variety of terrain and climate, it competes poorly with other small rodents in outdoor situations. Probably for this reason, on mainland Ireland it has been shown to be found commonly only in, or in the vicinity of, buildings (Fairley \& Smal, 1987). Thus, in rural Ireland at least, wild house mice exist essentially as a series of relatively isolated populations.

Genetic interchange between populations could be brought about either by movements of the mice themselves or by unintentional transfer by man. While there is no knowledge of the extent of the latter, the potential is considerable: for instance in the daily transport of bagged animal foods in an economy where the chief industry is still agriculture. Movement by the mice alone would most likely be characterized by some geographical discontinuity of phenotypes and a correlation of genetic divergence with distance. On the other hand, accidental carriage by man, not only over distances much greater than that travelled by a migrating mouse but significant even in relation to the total size of Ireland itself, would at least tend to obscure this. Frequent reintroduction of animals from outside Ireland is another possible complication. It is also relevant that house mice are characterized by great reproductive capacity and rapid population turnover. Populations are often unstable, especially in association with man where, for example, abrupt local increases and decreases in stored food may result in explosions and crashes in numbers. The potential for founder effects and rapid divergence is correspondingly great.

Territorial behaviour could also be a crucial factor in genetic interchange. Both sexes show aggression towards intruders, which may be killed, although female aggression is generally at a lower level (Crowcroft, 1966; Mackintosh, 1981). Even amongst residents some males defend territories, the remainder being non-territorial and subordinate, and the females mate mostly with territorial males. Such behaviour would obviously severely limit the genetic input from occasional intruders into an established population. Selander (1970) has, for example, demonstrated that populations of house mice inhabiting different barns on a single farm in the U.S.A. often differ significantly in allele frequencies and attributed this to territoriality. Notwithstanding, Berry et al. (1990) found that a large number of house mice introduced into a feral population on the Isle of May (Scotland) did contribute inter alia mitochondrial DNA ( $\mathrm{mtDNA})$ to the population.

The diversity of the house mouse, based on restriction analysis of mtDNA, has already been investigated from localities in Europe, North Africa, the Middle East and the Americas (Sage et al., 1990). The present study was undertaken to investigate polymorphism in mtDNA of the house mouse in Ireland, and to determine whether 
or not populations are likely to be formed mainly as a result of migration by mice themselves. In it we compare restriction fragments of the mtDNA of house mice from populations at sites at distances varying from under $1 \mathrm{~km}$ to over $258 \mathrm{~km}$ apart.

\section{Materials and methods}

\section{Collection of mice}

Mice were caught between September 1990 and January 1991 in Longworth live traps baited with oats, or occasionally were taken by hand. Because of the initial difficulty in obtaining suitable sites for trapping, a pragmatic approach was adopted and mice were eventually obtained from 14 locations as shown in Fig. 1 . The sites can be broadly classified under three headings.

1 West of Ireland. Lacagh, animal food store; Glenamaddy, poultry farm with animal food store; Tuam, mill; Galway, private house in housing estate; Kilrush, disused mill.

2 Wexford, buildings at wildfowl reserve, including food stores.

3 Belfast area. Dunmurry, motorway verge adjoining gardens of suburban houses; Castle Espie, cupboard in building on wildfowl reserve; Mountstewart, pig farm; Ballyblack, farm buildings; Craigantlet Farms ('Farms'), buildings on four farms.

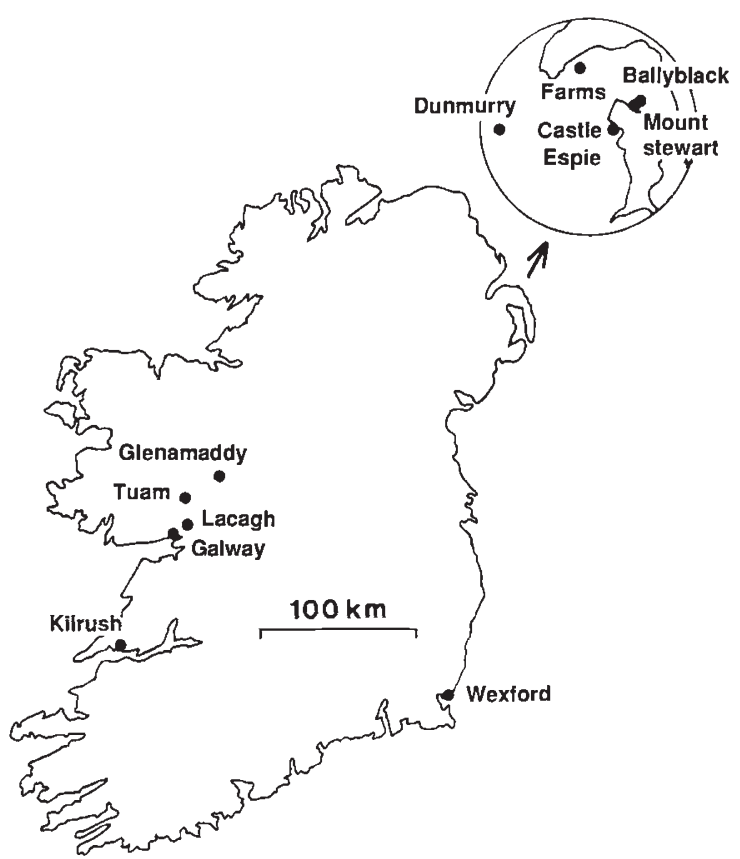

Fig. 1 Location of the sampling sites. The circle showing sites in the Belfast area is approximately $40 \mathrm{~km}$ in diameter. There were four farm sites the distances between these are $(1-2) 0.3 \mathrm{~km},(2-3) 2.4 \mathrm{~km},(3-4) 1.3 \mathrm{~km}$ and (1-4) $0.8 \mathrm{~km}$.
After capture, mice were transferred to laboratory cages modified for transport. Wood wool was provided as cover and bedding, and laboratory nuts and water $\mathrm{ad}$ libitum. There was some mortality but this may often have been the result of eating poison bait before capture.

\section{Biochemical techniques}

Animals were killed by crushing the cranium or by decapitation. We believe that the exsanguination following decapitation yields a cleaner mitochondrial preparation. The mice were then dissected to check the sex and to remove the livers for mtDNA analysis.

Mitochondria were prepared using a modification of Lansman et al.'s (1981) method and the mtDNA extracted by the method of Palva \& Palva (1985). mtDNA was digested with four restriction enzymes: HinfI and HaeIII (four base cutters), and BamHI and HindIII (six base cutters). The resultant fragments from the four cutters were separated on 5 per cent polyacrylamide gels and stained using the BioRad silverstain kit. Fragments from the six cutters were separated on 0.7 per cent agarose gels and stained with ethidium bromide.

\section{Results}

Results were obtained from a total of 74 mice. Some of the enzymes used produced large numbers of fragments, many of similar sizes. This necessitated careful assessment of homologies. A conservative approach was therefore taken which may occasionally have led to underestimation of the degree of polymorphism. The patterns of bands corresponding to the various phenotypes observed for HinfI, HaeIII, BamHI and HindIII are given in Figs, 2, 3, 4 and 5 respectively. All phenotypes obtained for individual mice at the various localities are recorded in Table 1 . It was not possible to obtain phenotypes with all enzymes for every individual because of the limited yield of mtDNA, and because restriction reactions were sometimes unsuccessful. As mtDNA is maternally inherited, the minimum number of clones (or composite phenotypes taking into account information from all restriction enzymes) at a site is equivalent to the minimum number of females which have contributed to the genetic composition of the population. The minimum number of foundresses in relation to the total number of animals sampled for each locality are given in Table 1 .

The statistical significance of apparent geographical discontinuity shown by individual phenotypes was evaluated using Fisher's exact test. (The alternatives, the $\chi^{2}$ and $G$-tests are limited by small numbers.) The test 


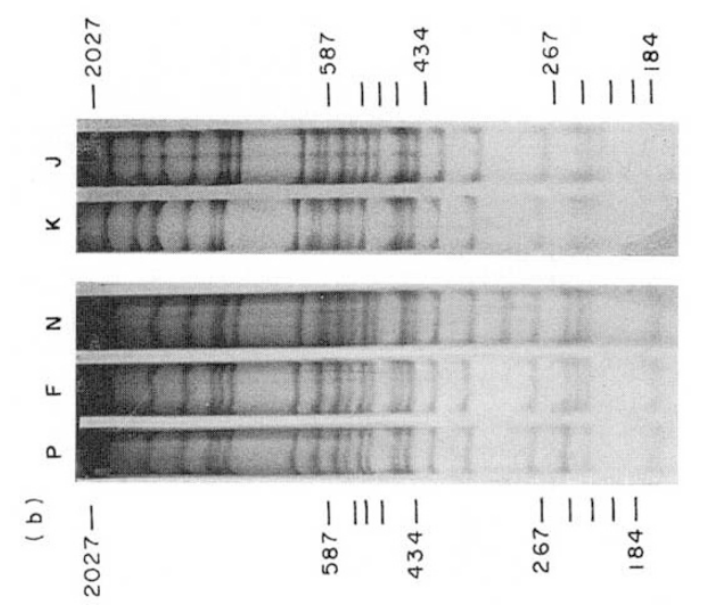

- II I I III I| $|1|||||||||||||$

$\times$ || ||$+||||||||||||||||||||$

$=\|$ | I II $\quad||\||\|||||||| \mid$

$>\|1|\||\||\|\|\|\| \| 11| 11$

> $\|$ I I II

$r \|||||$

os \|\|\|\|

$\propto\|\quad\| \| I$

$\circ\|\|\|\|$

a $\|||||$

$2\|||\|$

$=|||||||||||||||||||||||| \mid$

| | || ||| ||||||| || | | | ||

\& | | | || |||||||||||||| $\mid$

- | 11|||||||||||||||| | |||

$-1|1| \||||||||||||| \mid$

I ||||||||||||||||||||

0 $\| 11||||||||||||||||||$

* $\|||\||\|\quad||\|||\|| 1||$ | ||

* ||$\|\mid\|$ | $|\||\|\||||||$

- \| \|\|$\||\|\|\|\| \||||||$

- || | | ||| | | |||||||||| | | ||

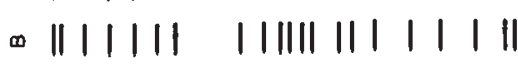

\& || || ||| | ||||| ||||| | ||

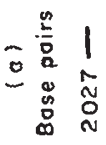

总䓵骂


$=|1|$ |II IIII |||||||| $\mid$

- III III IIIIIIII I I II

I ||||||||\|\||||||| $\mid$

० III I|| || || || | | | ||

4II || || || || | | | ||

w II| ||| || || || | | ||

- III III |||||I||| | |

$\infty \|||||||||||||||||$

ه III III |||| ||I | | ||
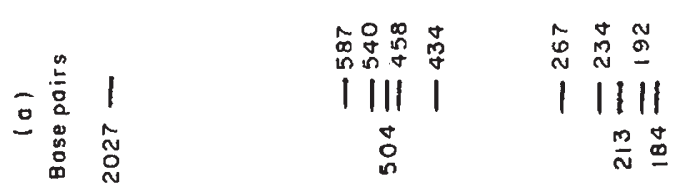


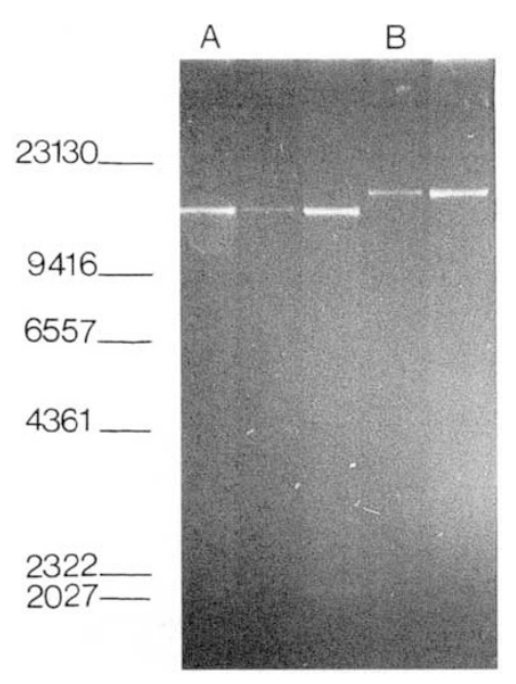

Fig. 4 Photograph of an agarose gel showing both phenotypes produced by restriction with $\mathrm{Bam} \mathrm{HI}$.

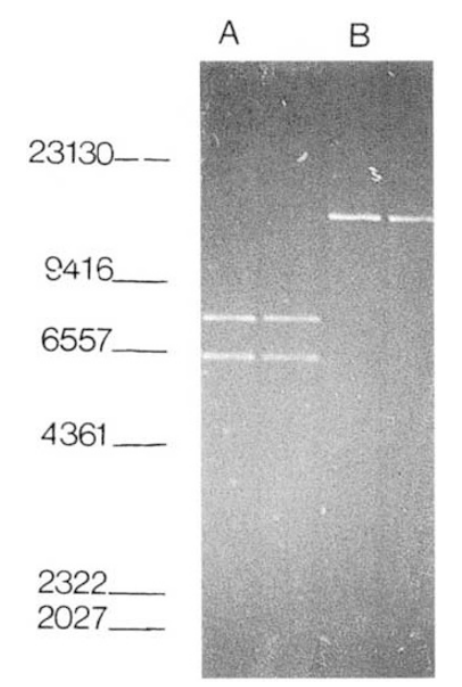

Fig. 5 Photograph of an agarose gel showing both phenotypes produced by restriction with HindIII.

was applied intuitively, i.e. when a phenotype occurred more than once and appeared to be isolated or was most common in a particular area. The results are given in Table 2. It may be observed that whereas several phenotypes produced results significant for individual localities, phenotypes representing three enzymes (Hinf I J HaeIII F, BamHI B) were localized in the Belfast area as a whole, and that two of these (HinfI J, BamHI B), which were common, were not recorded elsewhere. When a comparison is made between one group of localities and another, an intuitive approach might be questioned as the composition of the group is a matter of choice by the observer but the farms and the Belfast area each represent a
Table 1 All phenotypes determined for individual mice

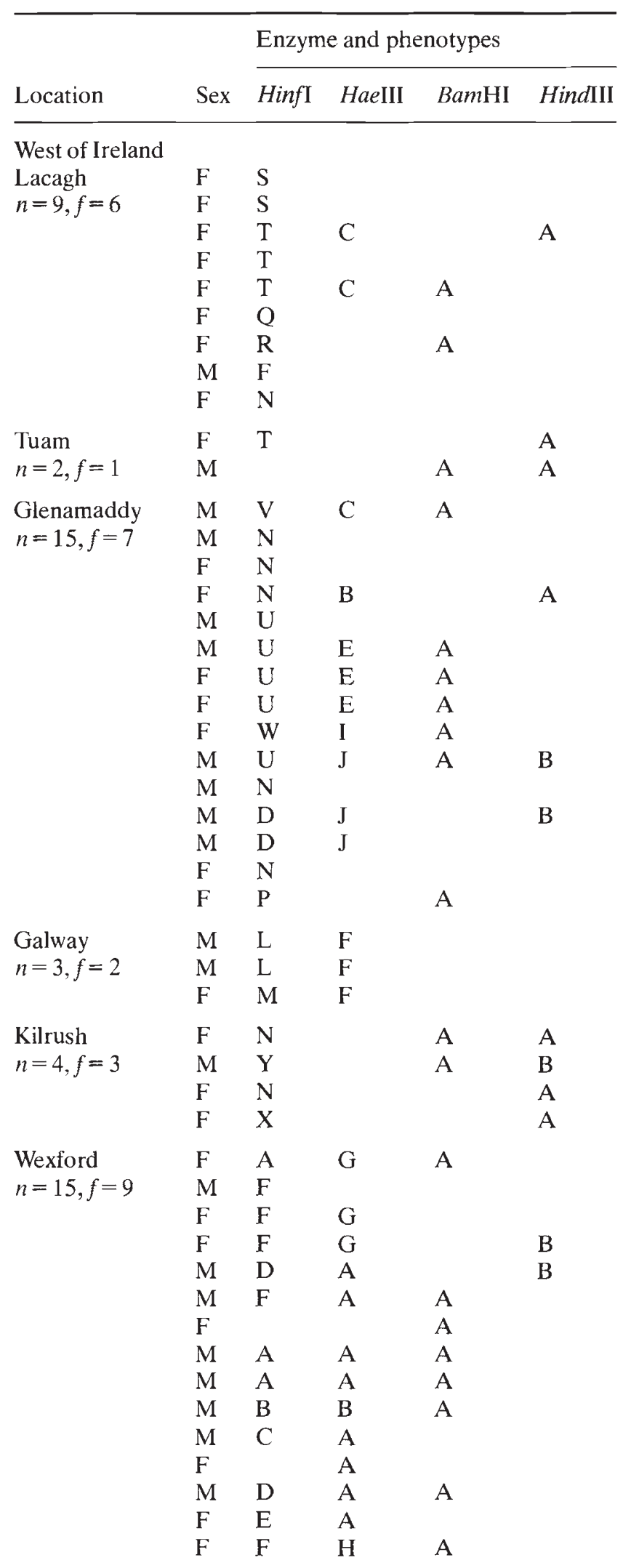


Table 1 Continued

\begin{tabular}{|c|c|c|c|c|c|}
\hline \multirow[b]{2}{*}{ Location } & \multirow[b]{2}{*}{ Sex } & \multicolumn{4}{|c|}{ Enzyme and phenotypes } \\
\hline & & $\operatorname{Hinf} \mathrm{I}$ & HaeIII & Bam HI & HindIII \\
\hline $\begin{array}{l}\text { Belfast area } \\
\text { Dunmurray } \\
n=3, f=1\end{array}$ & $\begin{array}{l}\mathrm{F} \\
\mathrm{M} \\
\mathrm{M}\end{array}$ & $\begin{array}{l}F \\
F \\
F\end{array}$ & $\begin{array}{l}F \\
F \\
F\end{array}$ & & \\
\hline $\begin{array}{l}\text { Ballyblack } \\
n=2, f=1\end{array}$ & $\begin{array}{l}\mathrm{M} \\
\mathrm{F}\end{array}$ & $\begin{array}{l}\mathrm{J} \\
\mathrm{J}\end{array}$ & $\begin{array}{l}F \\
F\end{array}$ & B & B \\
\hline $\begin{array}{l}\text { Mountstewart } \\
n=2, f=2\end{array}$ & $\begin{array}{l}\mathrm{F} \\
\mathrm{M}\end{array}$ & $\begin{array}{l}\mathrm{D} \\
\mathrm{J}\end{array}$ & $\begin{array}{l}\mathrm{A} \\
\mathrm{F}\end{array}$ & B & B \\
\hline $\begin{array}{l}\text { Castle Espie } \\
n=6, f=2\end{array}$ & $\begin{array}{l}\mathrm{F} \\
\mathrm{M} \\
\mathrm{F} \\
\mathrm{M} \\
\mathrm{F} \\
\mathrm{F}\end{array}$ & $\begin{array}{l}\mathrm{J} \\
\mathrm{D} \\
\mathrm{J} \\
\mathrm{J} \\
\mathrm{J} \\
\mathrm{J}\end{array}$ & $\begin{array}{l}\mathrm{F} \\
\mathrm{A} \\
\mathrm{F} \\
\mathrm{F} \\
\mathrm{F} \\
\mathrm{F}\end{array}$ & $\begin{array}{l}\mathrm{B} \\
\mathrm{A}\end{array}$ & B \\
\hline $\begin{array}{l}\text { Farm } 1 \\
n=3, f=2\end{array}$ & $\begin{array}{l}F \\
F \\
F\end{array}$ & $\begin{array}{l}\text { I } \\
G \\
G\end{array}$ & $\begin{array}{l}\mathrm{G} \\
\mathrm{G} \\
\mathrm{G}\end{array}$ & B & $\begin{array}{l}\mathrm{B} \\
\mathrm{B}\end{array}$ \\
\hline $\begin{array}{l}\text { Farm } 2 \\
n=2, f=2\end{array}$ & $\begin{array}{l}\mathrm{M} \\
\mathrm{F}\end{array}$ & $\begin{array}{l}\text { H } \\
\text { I }\end{array}$ & $\begin{array}{l}\mathrm{G} \\
\mathrm{G}\end{array}$ & B & B \\
\hline $\begin{array}{l}\text { Farm } 3 \\
n=3, f=1\end{array}$ & $\begin{array}{l}\mathrm{F} \\
\mathrm{F} \\
\mathrm{F} \\
\mathrm{M} \\
\mathrm{M}\end{array}$ & $\begin{array}{l}\mathbf{J} \\
\mathbf{J} \\
\mathbf{J} \\
\mathbf{J} \\
\mathbf{J}\end{array}$ & $\begin{array}{l}F \\
F \\
F \\
F \\
F\end{array}$ & $\begin{array}{l}\text { B } \\
\text { B } \\
\text { B }\end{array}$ & \\
\hline $\begin{array}{l}\text { Farm } 4 \\
n=4, f=2\end{array}$ & $\begin{array}{l}F \\
F \\
F\end{array}$ & $\begin{array}{l}\mathrm{K} \\
\mathrm{J} \\
\mathrm{J}\end{array}$ & $\begin{array}{l}F \\
F \\
F\end{array}$ & B & \\
\hline
\end{tabular}

$n=$ sample size,$f=$ minimum number of foundresses (clones present). The phenotypes are shown in Figs 2-5. combination of adjacent localities, and the $P$-values for the Belfast area are very small.

Homogeneity in the material from the Belfast area is further emphasized by a consideration of minimum foundresses. It is evident from Table 1 that the Lacagh sample had at least six foundresses, Glenamaddy seven and Wexford nine, but the combined samples from the whole of the Belfast area represent only seven.

The samples from the Craigantlet Farms fell into two groups as regards Hinfl and HaeIII. Farms 1 $(n=3)$ and $2(n=2)$ had clones IG, GG and HG; Farms $3(n=5)$ and $4(n=3)$ had JF and KF. Fisher's test on the distribution of $\mathrm{J}$ and $\mathrm{K}$ between the two pairs gives $P=4.7 \times 10^{-3}$ and $7.8 \times 10^{-4}$ respectively. However, the selection of pairs here is arbitrary, and one must therefore in each case add to $P$ the equally/less likely events of all five other possible combinations of two pairs of farms producing such an extreme result. This is approximated by multiplying by 6 , to give $P<0.05$ and $P<0.01$. Summing the two actual approximated levels of significance by Fisher's method gives $\chi^{2}=17.90$, 4 d.f., $P<0.01$.

The genetic distances between all composite phenotypes produced by HinfI and HaeIII were calculated. Phenotypes from other enzymes were not included because of the small number of results available. Thus, the mtDNA of 54 individuals representing 24 composite phenotypes was considered. The proportion of shared fragments $(F)$ between composite phenotypes was calculated using

$F=2 N_{\text {xy }} /\left(N_{\mathrm{x}}+N_{\mathrm{y}}\right)$

(Nei \& Li, 1979) where $N_{x y}$ is the number of bands shared by phenotype $x$ and $y$, and $N_{x}$ and $N_{y}$ are the total numbers of bands in phenotypes $x$ and $y$ respectively. Values of $F$ were converted to an approximation

Table 2 Phenotypes showing localization/geographical discontinuity statistical significant at the 5 per cent level determined by Fisher's Exact Test

\begin{tabular}{|c|c|c|c|c|c|c|c|}
\hline \multicolumn{2}{|c|}{$\begin{array}{l}\text { Enzyme and } \\
\text { phenotype }\end{array}$} & \multirow{2}{*}{$\begin{array}{l}\text { Locality } \\
\text { Wexford }\end{array}$} & \multirow{2}{*}{$\begin{array}{l}P \\
5.0 \times 10^{-3}\end{array}$} & \multicolumn{2}{|c|}{$\begin{array}{l}\text { Enzyme and } \\
\text { phenotype }\end{array}$} & \multirow{2}{*}{$\frac{\text { Locality }}{\text { Glenamaddy }}$} & \multirow{2}{*}{$\frac{P}{2.3 \times 10^{-4}}$} \\
\hline $\operatorname{Hinf} \mathrm{I}$ & A & & & $\operatorname{Hinf} \mathrm{I}$ & $\mathrm{U}$ & & \\
\hline $\operatorname{Hinf} \mathrm{I}$ & $\mathrm{F}$ & Wexford & $8.1 \times 10^{-3}$ & HaeIII & A & Wexford & $4.7 \times 10^{-5}$ \\
\hline HinfI & $\mathbf{J}$ & Belfast area & $8.4 \times 10^{-9}$ & HaeIII & $\mathrm{F}$ & Belfast area & $4.2 \times 10^{-6}$ \\
\hline $\operatorname{Hinf} \mathrm{I}$ & I & Farms & $3.1 \times 10^{-2}$ & HaeIII & $\mathrm{G}$ & Farms & $1.5 \times 10^{-2}$ \\
\hline $\operatorname{Hinf} \mathrm{I}$ & $\mathrm{L}$ & Galway & $1.2 \times 10^{-2}$ & HaeIII & $\mathrm{C}$ & Lacagh & $2.1 \times 10^{-3}$ \\
\hline Hinf I & $S$ & Lacagh & $1.4 \times 10^{-2}$ & HaeIII & $\mathrm{E}$ & Glenamaddy & $3.4 \times 10^{-3}$ \\
\hline \multirow[t]{2}{*}{ Hinf $\mathrm{I}$} & $\mathrm{T}$ & Lacagh & $5.5 \times 10^{-3}$ & HaeIII & $\mathbf{J}$ & Glenamaddy & $3.4 \times 10^{-3}$ \\
\hline & & & & Bam HI & B & Belfast area & $1.7 \times 10^{-7}$ \\
\hline
\end{tabular}


of $P$ (i.e. the fraction of base substitutions, multiplied by 100 to give percentage sequence divergence) using Upholt's (1977) equation

$P=1-\frac{\left[-F+\sqrt{ }\left(F^{2}+8 F\right)\right]^{1 / n}}{2}$

where $n$ is the number of base pairs present in the restriction site. The enzyme HinfI was considered to be a four-cutter for the purposes of this calculation. The maximum sequence divergence registered was 1.166 per cent between $\mathrm{AA}$ and $\mathrm{IG}$, and between CA and IG (AA, CA Wexford, IG Graigantlet Farms).

Sequence divergence and geographical distance were calculated between all permutations of all composite phenotypes at all sites. Of course, where the same composite phenotype occurred at two sites the sequence divergence was zero. The results are plotted in Fig. 6. There was a highly significant positive correlation between genetic divergence and geographical distance, Spearman's rank correlation giving $z=5.667$ $P<10^{-7}$. The use of a test of correlation might be queried because the geographical distances are bimodal: either short $(<50 \mathrm{~km})$ or long $(>200 \mathrm{~km})$. Notwithstanding, a comparison of the mean sequence divergence of these two groups, using a Mann-Whitney test, gives $z=6.256, P<10^{-9}$. In addition, Spearman's rank correlation applied to the short distance data alone gives $z=1.802, P<0.08$, which approaches the 5 per cent level of significance. Although data are limited, it is interesting that on Fig. 6 there is no clear difference apparent between the $>30-50 \mathrm{~km}$ category and categories $>200 \mathrm{~km}$.

\section{Discussion}

Ferris et al. (1983), working on Mus musculus domesticus, found almost an exact correspondence between dendrograms produced using restriction mapping of the recognition sites of 11 enzymes and fragment comparison using only two enzymes, HinfI and $\mathrm{MboI}$. In the present study two enzymes, HinfI and HaeIII, were used to provide an approximation of genetic divergence.

In view of the small numbers of samples taken, the relatively high minimum numbers of founders appear remarkable, even setting aside that these figures are minima and that a limited range of restriction enzymes was used. Nevertheless, although house mice are territorial, the ranges indoors, where food is abundant, are so small (Southern, 1954; Crowcroft, 1966) that there could be repeated colonization of suitable premises, provided that the initial colonizers did not reproduce themselves and occupy available space first. In addi-

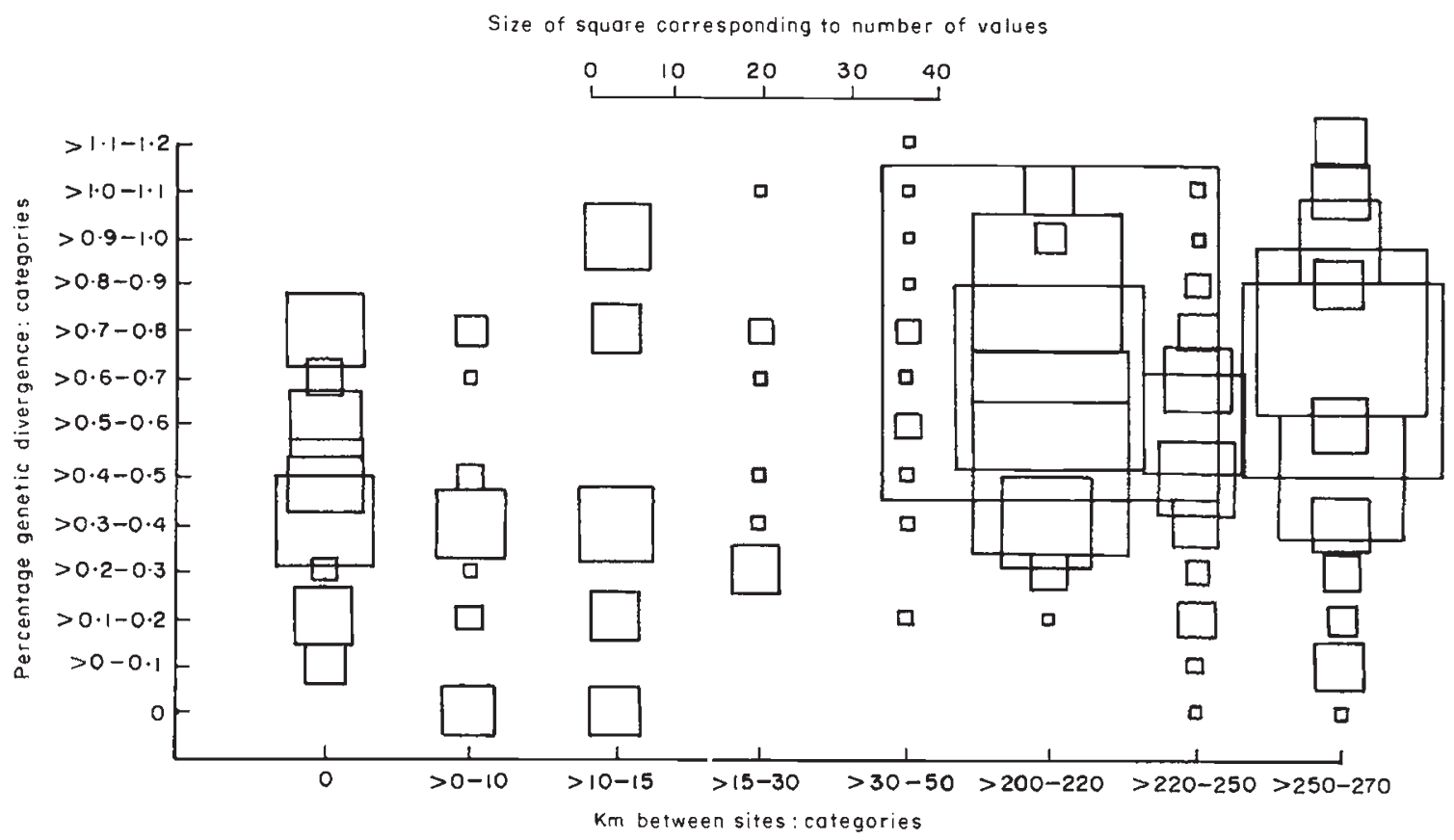

Fig. 6 Scatter plot of percentage genetic divergence (composite for HinfI and HaeIII) against geographical distance between all phenotypes at all sites. For the sake of clarity both divergence and distance are given in categories here, and point overlap is represented by the size of the square. The scale at the top gives the size of square corresponding to the number of overlapping values. 
tion, control by poisoning (at most sites) and trapping (at Wexford) would favour repeated colonization.

A correlation between geographical and genetic distance for $M . m$. domesticus has already been demonstrated for nuclear loci by Britton-Davidian (1990). Nevertheless this was over a distance of about $100 \mathrm{~km}$. With more widespread populations in Europe she found that 'genetic divergence between populations varied greatly but did not appear to be highly structured geographically'. Ferris et al. (1983) concluded that there was a correlation between mtDNA divergence and short geographical distance for $M$. $m$. domesticus, but over long distances (such as those between states in the U.S.A.) found no such correlation. The strong association between geographical and genetic distance demonstrated here, together with the marked discontinuity in some of the phenotypes, suggests that any transfer of mice over relatively long distances (necessarily by man) does not lead to significant genetic change. It appears that successful emigration is most likely from nearby populations. Note that Baker \& Petras (1986) found that some house mice displaced from emptied corn cribs in Ontario, Canada, were able to disperse over cultivated and uncultivated terrain and eventually take up residence in other cribs.

While it is tempting to explain the apparent relative homogeneity in the mice from the Belfast area by a possible common origin (and north-east Ireland was extensively settled from Great Britain in the seventeenth century), the explanation may simply be the proximity of the sites to one another. The most widely separated are $<25 \mathrm{~km}$ apart.

The separation of the Craigantlet Farms into what appears to be two natural groups of $1-2$ and 3-4 is most readily explained by some topographical feature acting as a barrier to movement. A 5-m wide tarred road splits the farms into these pairs and this could well account for the results. A migrating house mouse, when faced with the choice of crossing such a road, or proceeding in the hedgerows along the verges, is arguably more likely to take the latter option. Clearly a detailed study of restriction fragments from mtDNA in mouse populations in a small rural area could cast considerable light on the origins of individual populations, migration of mice and barriers to movement.

\section{Acknowledgements}

We are indebted to R. Deering, P. Purcell, the Irish Wildlife Service, the Traffic Division of the Northern Ireland Department of the Environment, and others who wish to remain anonymous, for permission to trap at the various locations. We should also like to thank Dr I. Montgomery, who caught all the mice from the Craigantlet Farms, and B. Dawson, M. Foster, A. Grainger, E. MacLoughlin, M. Mullen, O. O'Brien and T. Sloan for technical help.

\section{References}

AUFFREY, J., VANLERBERGHE, F. AND BRITTON-DAVIDIAN, J. 1990. The house mouse progression in Eurasia: a palaentological and archaeozoological approach. Biol. J. Linn. Soc., 41, 13-25.

BAKER, A. E. AND PETRAS, M. L. 1986. The fate of Mus domesticus demes after destruction of their habitats. Biol. J. Linn. Soc., 41, 81-88.

BERRY, R. J., TRIGGS, G. S., BAUCHAU, V., JONES, C. S. AND SCRIVEN, P. 1990. Gene flow and hybridization following introduction of Mus domesticus into an established population. Biol. J. Linn. Soc., 41, 279-283.

BRITTON-DAVIDIAN, J. 1990. Genic differentiation in Mus musculus domesticus populations from Europe, the Middle East and North Africa: geographic patterns and colonization events. Biol. J. Linn. Soc., 41, 27-45.

CROWCROFT, P. 1966. Mice all Over. Foulis, London.

FAIRLEY, J. S. AND SMAL, C. M. 1987. Feral house mice in Ireland. Ir. Nat. J., 22, 284-290.

FERRIS, S. D., SAGE, R. D., PRAGER, E. M., RITTE, U. AND WILSON, A. C. 1983. Mitochondrial DNA evolution in mice. Genetics, 105, 681-721.

MACKINTOSH, J. H. 1981. Behaviour of the house mouse. Symp. Zool. Soc. Lond., 47, 337-365.

LANSMAN, R. A., SHADE, R. O., SHAPIRA, J. F. AND AVISE, J. C. 1981. The use of restriction endonucleases to measure mitochondrial DNA sequence relatedness in natural populations. Mol. Evol., 17, 214-226.

NEI, M. AND LI, W. 1979. Mathematical model for studying genetic variation in terms of restriction endonucleases. Genetics, 76, 5269-5273.

PALVA, T. K. AND PALVA, P. 1985. Rapid isolation of animal mitochondrial DNA by alkaline extraction. FEBS Lett., 192, 267-270.

SAGE, R. D., PRAGER, E. M., TICHY, H. AND WILSON, A. C. 1990. Mitochondrial DNA variation in house mice, Mus domesticus (Rutty). Biol. J. Linn. Soc., 41, 105-123.

SELANDER, R. K. 1970. Biochemical polymorphism in populations of the house mouse and old-field mouse. Symp. Zool. Soc. Lond., 26, 73-91.

SOUTHERn, H. N. (ed.) 1954. Control of Rats and Mice Vol. III. House Mice. Clarendon Press, Oxford.

UPHOLT, W. B. 1977. Estimation of DNA sequence divergence from comparison of restriction endonuclease digests. Nucl. Acids Res. 4, 1257-1265. 